\title{
Chegou o ruidoso!: ecos de uma dor antiga em Perdição, de Hélia Correia*
}

\author{
Chegou o ruidoso!: echoes of an old pain in Perdição, of Hélia Correia
}

\author{
SAMARKANDRA Pereira dos SANTOS PIMENTEL \\ Universidade Federal da Paraíba
}

Resumo: Este artigo analisa o coro de bacantes do drama Perdição: Exercício sobre Antígona (1991), da autora portuguesa Hélia Correia, atentando tanto para as diferenças e similaridades com a tragédia As Bacantes, de Eurípedes e com o prólogo de Antígona, de Sófocles, como para os aspectos de sua composição que não remetem à antiguidade clássica ao conjugar elementos românticos e pós-modernos.

Palavras-chave: Hélia Correia; tragédia; mito.

\begin{abstract}
In this article, the bacchantes choir in drama Perdição: exercício sobre Antígona is analyzed with respect as to the differences and similarities with the tragedy The Bachae, by Eurípides and with the Antigone's prologue, by Sophocles, as to aspects of its composition that do not regard the classical age mixing romantic and post-moderns elements.
\end{abstract}

Keywords: Hélia Correia; tragedy; mith.

Talvez o sangue se lhes arrefeça um pouco, e pensarão:

"Não há razões para ter medo.

Nem sequer deverei tomar partido."

(Tirésias de Perdição)

\section{Introdução}

Hélia Correia compôs uma trilogia de peças míticas e Perdição: Exercício sobre Antígona (1991) foi a primeira delas. Levados pelo seu subtítulo que já anuncia sua protagonista, pensamos estar diante de um texto cujas chaves de decifração nos são familiares, porém, esta clareza cessa exatamente no início da leitura da peça. Desde o início, temos contato com um coro feminino, que nos remete à outra tragédia grega, As bacantes, de Eurípedes, que permeará toda a peça e terá como característica o oscilar entre a alegria e a tristeza diante do que expõe, possibilitando-nos aproximá-lo do percurso traçado por Antígona rumo ao trágico, à perdição.

Nossa proposta é analisar somente o coro da peça, entretanto, cabe-nos apresentar alguns dados acerca de Perdição. A ação dramática é única e gira em torno de Antígona. O tempo em que ocorre esta ação ultrapassa as 24 horas, mas não sabemos exatamente precisar em quantos dias ela se dá. Dentre as regras básicas da arte teatral, é o lugar que ganha relevo, visto que o cenário se subdivide em três dimensões:
1. O mundo dos vivos, onde interagem Antígona, sua Ama, Ismena, Eurídice, Hémon, Creonte e seu Criado, mensageiro e os guardas;

2. O mundo dos mortos, onde somente Antígona e a Ama dialogam;

3. E o plano de Tirésias ${ }^{1}$ que, à distância, preside e reflete acerca dos acontecimentos. O adivinho aparecerá três vezes durante a peça: no prólogo, na introdução à segunda cena e no epílogo.

\footnotetext{
* Em 2014, defendemos nossa tese de doutorado em Letras, pela UFPB, intitulada "Paródia e mecanismo mimético em Perdição: exercício sobre Antígona, de Hélia Correia", em que analisamos o referido drama. O artigo aqui apresentado é, com algumas alterações, parte deste trabalho. Segundo Junito Brandão (1992), o vate cego "possuía o dom da mantéia, da adivinhação" (BRANDÃO, 1992, p. 75). Há mais de uma versão para a causa da sua cegueira. As duas mais conhecidas se referem à sua participação na querela entre Hera e Zeus acerca do prazer sexual. Perguntado qual era o sexo que sentia mais prazer, Tirésias afirma que a mulher, assim, Hera, contrariada, cega-lhe e Zeus, compadecido de sua situação, dá-lhe o dom da adivinhação. A outra versão se refere à deusa Atena e à sua mãe Cáriclo. Ambas tomavam banho e Tirésias, ainda jovem as viu nuas, assim, como castigo, Atena o cegou. A ninfa Cáriclo reclamou a Atenas por tamanha crueldade. A deusa, assim, deu-lhe o dom da predição e, junto a ele, um bordão mágico para ajudar-lhe a se guiar.
} 
O coro de bacantes permeará todas as dimensões mencionadas acima, contudo, não dialogará diretamente com nenhuma delas.

A peça de Hélia Correia se inicia com o párodo, o canto ritualístico do coro formado pelas bacantes, no Citéron, porém, ele é marcado por uma "perdição de sentidos" (aparentemente, daí o título da obra) que nos mostra uma funesta realidade. Assim, este canto mais se assemelha a um êxodo, visto que é no final da tragédia que seu herói não só reconhece seus erros, como recebe o seu castigo divino. Com isso, consideramos oportuna a ideia de que Perdição seria uma 'continuidade'2 da Antígona sofocliana, tal como a Eneida continua os poemas homéricos, se levássemos em conta somente estas informações. Porém, não podemos nos furtar de relacioná-lo ao coro de As bacantes, de Eurípedes, e ao prólogo da Antígona sofocliana, declamado por Dioniso. Daí a relevância de retomarmos os conceitos de paródia para esta tentativa de apreensão deste coro heliano, visto que seu caráter paradoxal pode nos causar prazer, tal como constata Hutcheon (1988), mas, certamente, traz-nos problemas, tamanho é seu caráter auto-reflexivo, distinto do contexto histórico-político no qual está inserido.

\section{A tragédia grega no Coro de bacantes de Perdição}

Como já indicamos, há elementos que indicam ser o coro de Perdição uma paródia tanto de As Bacantes, de Eurípedes, como também do prólogo de Antígona, de Sófocles.

Em Perdição, Hélia Correia nos informa que "um hino a Dioniso será entoado ao longo da peça, nas mudanças de cena, nos silêncios, ou como fundo em certos diálogos". Percebemos a forte ligação do lamento exposto pelas bacantes no ditirambo que permeia o drama com o percurso de sua heroína rumo ao trágico. No coro de Perdição fica patente que há, no caráter orgiástico do drama, um apelo paródico à sua continuidade com um tom que certamente serve de alerta à nós, leitores/ espectadores. Lembremos que Eurípedes, no prólogo d'As Bacantes, apresenta-nos Dioniso justificando suas ações "contra" as mulheres de Tebas que ele torna suas seguidoras, por terem as mesmas desdenhado de sua origem divina (vv. 46-54):

Em altos brados, elas proclamavam que, se Zeus a fulminou [sua mãe Sêmele], foi para castigá-la por ter tido a idéia de vangloriar-se de amores com um deus. Por isso compeli todas as mulheres de Tebas a deixarem seus lares sob o aguilhão de meu delírio. E agora, vítimas da mente transtornada, elas passaram a morar nos altos montes, usando apenas a roupagem orgiástica (EURÍPEDES, 2002, p. 210).
O intento de Dioniso é fazer com que Tebas reconheça "a grande falta que lhe fazem" suas danças e mistérios, para que ele "possa vingar a honra de Sêmele", insultada, por dizerem às outras que seu filho não era de Zeus. Logo, em seguida, surge o coro de bacantes, que, tresloucadas, cantam (vv. 177-185):
Viemos apressadas lá da Ásia
e do sagrado Tmolo - doce esforço
gostoso de sofrer, pois é por Brômio ${ }^{3}$.
(...)
É doce para nós nos altos montes, quando saímos da corrida báquica, ficar deitadas na relva abundante sob a pele da corça, e capturar um bode para ser sacrificado e devorar a sua carne crua, extasiadas, enquanto corremos pelos montes da Frígia, ou então nos montes lídios levadas por Brômio! (EURÍPEDES, 2002, p. 213-214).

Tirésias é o primeiro personagem que dialoga em As Bacantes, de Eurípedes. Ele então pede a Cadmo, o fundador de Tebas, crendo ter ao seu "lado a límpida verdade" (vv. 247) (EURÍPEDES, 2002, p.216), que permita a celebração dos ritos a Dioniso, pois, "quem não fizer o mesmo será um demente" (vv. 248) (EURÍPEDES, 2002, p. 216).

Como sabemos, o excessivo Penteu, neto de Cadmo e rei de Tebas, ignora qualquer apelo em prol de Dioniso. Assim, manda acorrentar o deus que, também desmesurado, em um "divino terremoto" (vv.748), deixa o castelo de Penteu semidestruído, e diz às suas bacantes que se jogaram ao chão: “(...) Levantai-vos, / acalmai vossos corpos expulsando deles / o habitual tremor causado pelo medo (vv. 771-773)" (EURÍPEDES, 2002, p. 235).

Outra passagem relevante para o nosso estudo é a que mostra Penteu, descrente do poder do deus da desmesura, sendo induzido por Dioniso a desejar ver as bacantes no Cíteron. O rei, mesmo desconfiando que se trate de um ardil por parte do deus, cai em sua armadilha (vv. 10771084):

Dioniso - Gostarias de vê-las soltas nas montanhas? Penteu - Por certo, mesmo que custasse muito ouro. Dioniso - De onde te veio este desejo violento?

\footnotetext{
Esta nossa suposição nasceu a partir da nossa leitura de Longino que, no capítulo XIII de seu Tratado, indicou um caminho para se atingir o sublime: "a imitação e inveja dos grandes prosadores e poetas do passado" (LONGINO, 1997, p. 85).

3 N'As bacantes, o deus também é denominado de Brômio, o "Fremente" (JAA TORRANO apud EURÍPEDES, 1995, p. 20). Girard (2008) observa que sob este epíteto, Dioniso preside vários desastres "que reclamam sempre a presença de uma multidão incitada pelo terror insensato a atos extraordinários, quase sobrenaturais" (GIRARD, 2008, p. 170).
} 
Penteu - Devo dizer que ficaria compungido ao vê-las nessas condições constrangedoras.

Dioniso - Então sentes vontades de presenciar um espetáculo que te causa desgosto?

Penteu - Sinto, mas escondido entre os altos pinheiros (EURÍPEDES, 2002, p. 246).

Girard (1998) constata que Dioniso e Penteu "não disputam nada de concreto" (GIRARD, 1998, p. 181), visto que disputam a própria divindade, "mas sob a divindade só há violência" (GIRARD, 1998, p. 181). Certos disso, cabe-nos apresentar a definição de kydos, que é próxima a de divindade.

Com base em Le vocabulaire des instituitions indoeuropéennes, de Benveniste, que traduz o termo por "talismã de supremacia", Girard (2008a) conclui:

O kydos é a fascinação exercida pela violência. Onde quer que se mostre, ela seduz e atemoriza os homens; nunca é simples instrumento, mas epifania. Desde que ela apareça, a unanimidade tende a se realizar, contra ela ou a seu redor, o que significa o mesmo. Suscita um desequilíbrio, fazendo o destino inclinar-se para um lado ou para outro. O menor acontecimento violento tende a transformar-se em bola de neve, tornando-se irreversível. Os que detêm o kydos vêem sua força multiplicar-se, os que dele são privados têm os braços presos ou paralisados. Aquele que acaba de desfechar seu golpe sempre possui o kydos: o vencedor do momento, que faz que os outros acreditem, e que imagina também que a sua violência triunfou definitivamente. Os adversários do triunfador devem dispender um esforço extraordinário para escapar do encantamento e recuperar o kydos (GIRARD, 2008a, p. 191).

Na sequência de As Bacantes, o que vemos é Penteu pedindo a ajuda de Dioniso para realizar o seu desejo, que será prontamente atendido, mas não sem antes o rei passar por algumas mudanças no vestir, visto que seria estripado pelas mênades se aparecesse "descoberto". Assim, porá vestes de linho, peruca, manto, mitra, um tirso e "a pele de corça malhada" (vv. 1103). Enceguecido pela divindade, Penteu, mesmo achando inadequado se vestir de mulher, e, com isso, abrindo mão de comandar os seus "soldados" (vv.1113) cai no estratagema de Dioniso, que assim o prepara ritualisticamente para torná-lo uma vítima expiatória. Como todos, inclusive, velhos, exaltarão o deus em seu culto, pois, tal como anuncia Tirésias (vv.261-265):

O deus, não faz a menor distinção entre as idades; são iguais jovens e velhos em seus sagrados coros; ele quer apenas receber homenagens de todos os crentes, pois em seu culto não há discriminações (EURÍPEDES, 2002, p. 217).
A fúria homicida de Dioniso se propagará para toda comunidade, conditio sine qua non para o fim da crise.

Assim, Penteu é travestido em monstro, sendo flagrado e estraçalhado pelas bacantes. Depois de morto, no colo da mãe, Agave, a metamorfose (vv. 1545-1548): "- Que bezerrinho lindo! Ainda cresce / na cabecinha do pobre animal / um pelo bem macio e abundante!" (EURÍPEDES, 2002, p. 265).

Depois que Agave experimenta uma anagnorisis, ao ver que está diante do filho morto, ocorre uma peripeteia, e, se antes a mesma era feliz, agora ela lamenta seu infortúnio (vv. 1672): “Agave - Não... Ai de mim!... trouxe a cabeça de Penteu..." (EURÍPEDES, 2002, p. 272).

Maior anagnorisis ocorre quando descobre que, enlouquecida pelo deus, ela mesma, dançando inebriada junto às bacantes, o matara (vv. 1685): "Agave - Agora compreendo... Perdeu-nos Diôniso..." (EURÍPEDES, 2002, p. 272).

Uma das últimas falas de Dioniso, ao se referir à causa da morte de seu antagonista poderia, facilmente, ter sido dita por Penteu e endereçada ao deus (vv. 1745-1749):

Pecando por despeito e por brutalidade ele tratou injustamente um benfeitor, encarcerando-o de maneira humilhante, cobrindo-o de ultrajes (EURÍPEDES, 2002, p. 275).

Como vemos, não foi um objeto que gerou o conflito. Assim, a solução encontrada pelos rivais é a invenção de pretextos para desencadear a violência (GIRARD, 2008a, p. 182).

Deste modo, Dioniso “perturba a paz" que ele próprio buscara engendrar. A justificativa para a sua ação divina é que foi tomado por uma "cólera legítima contra uma hýbris blasfematória", porém, conforme constata Girard (2008a), é impossível diferenciá-las "até o momento da unanimidade fundadora" (GIRARD, 2008a, p. 171).

Note-se que Dioniso, com sua ação, castiga não só Penteu, como toda Tebas, por não o reconhecer como filho de Zeus. Em suas ações, aniquila um genos inteiro. Condena as bacantes a partirem de Tebas, pois (vv. 1756-1757): "Os assassinos nunca mais terão direito/ de viver perto da tumba de suas vítimas" (EURÍPEDES, 2002, p. 275).

Foi a partir de Nietzsche e de Rudolf Otto que surgiu uma visão "deleitável" das ações violentas de Dioniso. Girard (2008a) constata que, por isso, o leitor desprevenido:

[...] sempre se espanta com o caráter odioso de Dioniso. Durante toda a tragédia, o deus erra pela cidade semeando a violência em sua passagem, provocando o crime com a arte de um sedutor diabólico. Somente o donquixotismo masoquista de um mundo tão protegido da violência essencial, como é ainda o nosso, pôde 
encontrar algo de deleitável no Dioniso d'As Bacantes. Segundo todas as evidências, Eurípedes permanece alheio a estas ilusões, que seriam completamente cômicas se não fossem inquietantes (GIRARD, 2008a, p. 169).

Para que este argumento fique mais claro, devemos citar tanto o último lamento de Agave, como as considerações finais do coro, que, de maneira ambígua, justifica as ações de Dioniso (vv. 1823-1832):

Agave - [...] Vamos até onde o Cíteron execrável não possa ver-nos nem meus olhos possam vê-lo, lugares onde nada me faça pensar em meus cortejos! Cuidem disso outras Bacantes!

Coro - A vontade de um deus tem muitas formas e muitas vezes ele surpreende-nos na realização de seus desígnios. Não acontece o que era de esperar e vemos no momento culminante o inesperado. Assim termina o drama (EURÍPEDES, 2002, p. 279).

Como vemos, se há dúvida no que diz o coro, que parece justificar a ira de Dioniso, o lamento de Agave é categórico, pois, ela manda um recado às seguidoras do deus da desmesura e à plateia: que olhemos para as vítimas. Porém, apesar de proferido em alto e em bom som, o bramido sincero da mãe de Penteu não repele do Cíteron as bacantes recriadas por Hélia Correia (nem a nós), mas é a sua a dor que ecoa e, mesmo que a sua repercussão não chegue claramente, é o suficiente para que as prosélitas do deus questionem a validade das ações de Dioniso.

Algo similar ocorre no estásimo $\mathrm{V}$ na Antígona, de Sófocles. Nele, há uma invocação ao deus da cidade realizada pelo Coro, em sua última aparição, como derradeiro recurso para um desfecho feliz:

Deus de múltiplos nomes, alegria da virgem Cadméia, da mesma raça de Zeus tonitruante, protetor da Itália gloriosa, tu, que reinas no fundo vale aonde todos vão, sacrário de Deméter Eleusínia, Baco, patrono da cidade-mãe das Bacantes, de Tebas que se alonga pelo caminho líquido do Ismeno sobre a semente do dragão feroz! (vv. 1240-1148) (...)

E agora, que a cidade e o povo todo são presas de um flagelo violento, vem, com teus purificadores pés, pelas alturas do monte Parnaso ou cruza, então, o ruidoso passo! $\mathrm{Tu}$, condutor das danças das estrelas ígneas, maestro das noturnas vozes, criança de Zeus poderoso, rei, mostra-te a nós com o séquito da Tíades de Naxos, que em bailados delirantes, intermináveis, pela noite adentro te adoram, Íaco, rei generoso! (vv. 1262-1273) (SÓFOCLES, 1989, p. 242-243).

Logo após vem o êxodo e então somos informados, pelo mensageiro, da mudança de sorte de Creonte, que se encaminhava para libertar Antígona: Antígona está morta e, por isso, Hémon se matou. Um segundo mensageiro lhe diz que após Eurídice saber da morte do filho, também se suicidou.

Sutil é o papel do coro, pois, após chamar pelo deus da desmesura, evocando a sua generosidade, testemunha os fins trágicos dos envolvidos no conflito. Com isso, vemos claramente a violência descrita em termos de sacrifício. Mas a contradição maior fica por conta dos anapestos finais, através dos quais este mesmo coro lamenta a falta de bom senso dos tebanos (vv. 1347-1353):

Para ser feliz, bom senso é mais que tudo.

Com os deuses não seja ímpio ninguém.

Dos insolentes, palavras infladas

Pagam a pena dos grandes castigos;

A ser sensatos os anos the ensinaram (SÓFOCLES, 1989, p. 246).

Como ocorre entre Agave e o coro de As Bacantes, o trecho citado acima é mais um do "véu poético" lançado pelo poeta "sobre realidades que seriam na verdade sórdidas" (GIRARD, 2008a, p. 11-12).

Isto posto, partamos, então, à análise do coro de Perdição.

Como vimos, n'As bacantes, de Eurípedes, o deus Dioniso impera durante toda a ação dramática. Suas seguidoras, tomadas pelo êxtase divino, têm a mera função de executar suas ordens. Em Perdição, Hélia Correia parodia a tragédia euripidiana no seu coro ditirâmbico que, dividido em dez estrofes, é protagonizado pelas bacantes. Dioniso, por sua vez, não se pronunciará durante a ação, mas se fará presente por meio do tremor e temor incutido em suas seguidoras, estas personagens "excêntricas", tal como definiu Hutcheon (1988): "daqueles [tipos] que são marginalizados por uma ideologia dominante" (HUTCHEON, 1988, p. 58). Assim, Hélia Correia "usará e abusará" criticamente da tragédia euripidiana referida e fará o coro, esta personagem coletiva, apontar "autoconscientemente para os próprios paradoxos e o caráter provisório" (HUTCHEON, 1988, p.43) de suas ações. Com isso, veremos aqui também o desnudamento do mecanismo mimético girardiano e a constatação de que a busca pela "divindade" (que é similar ao kydos) só gera destruição e ruína.

$\mathrm{Na} 1^{a \underline{a}}$ estrofe do coro, vemos a evocação a Dioniso, marcada por um profundo erotismo e a afirmação de que 
o deus da desmesura é, paradoxalmente, o "o mais terrível e o mais doce" deles:

Pelo fogo da língua,

pelo sopro e o contágio da língua.

Pela boca,

os buracos do corpo que nos ligam

ao estrume

e ao alimento.

Os buracos do corpo onde entram o homem.

E escorrem as sangrias,

por onde nos rebentam as crianças,

Ó bodezinho,

Ó tocador da flauta que nos leva à loucura (CORREIA, 1991, p. 17).

$\mathrm{Na} 2^{\mathrm{a}}$ estrofe, surge a descrição do comportamento e gestos das bacantes e alguns aspectos rituais da oreibasia (a corrida pelas montanhas), com sua dança ritual, o balançar das cabeças e o sparagmos (dilaceração das vítimas). Porém, estas ações, no fim da estrofe, geram um questionamento de caráter autorreflexivo:

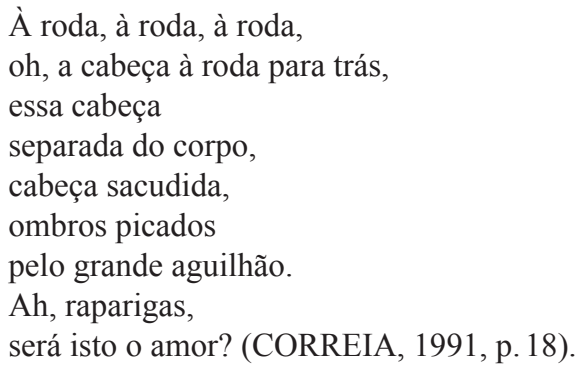

Segundo Hutcheon (1988), a paródia repete o modelo parodiado "com distância crítica que permite a indicação irônica da diferença no próprio âmago da semelhança" (HUTCHEON, 1988, p.47). No párodo euripidiano de As bacantes, vemos as mênades que abandonam "os seus afazeres (...), tangidas pelos aguilhões de Báquio" (vv. 158-161), para, em seguida, extasiadas, "nos altos montes", (...) "capturar um bode para ser sacrificado e devorar a sua carne crua" (vv. 176-182). Não surge, nesta passagem do drama de Eurípedes, nenhum elemento que ponha em dúvida a validade das ações das bacantes, embora, mais adiante, com a aparição do $2^{\mathrm{O}}$ Mensageiro (vv. 1398-1416), responsável por descrever o que viu no Cíteron, vejamos algum questionamento acerca da ação de Dioniso, que entrega Penteu às suas seguidoras e ordena que elas o mate:

"Entrego-vos, filhas queridas, este homem que riu de vós, de mim e de meus sacros ritos.

Agora é a vossa vez! Agi! Vingai-vos dele!"

Enquanto ele falava uma chama divina

brilhou a certa altura unindo a terra ao céu.

Depois o ar silenciou e a folhagem

do vale coberto de bosques se calou e ninguém mais ouvia gritos de animais. As Mênades não entenderam no momento a instigação do deus; elas se levantaram voltando os olhos para todos os recantos, e o deus teve de repetir a sua ordem; tomando consciência do comando báquico, as filhas do vivido Cadmo, num impulso não menos repentino que o das alvas pombas, puseram-se a saltar, e a ânsia de correr apoderou-se da mãe de Penteu - Agave -, e de suas irmãs e das Bacantes todas (EURÍPEDES, 1993, p. 260). (Grifo nosso)

Observamos que, mesmo tomadas pelo transe, as mênades não compreendem a ordem dada pelo deus, possivelmente, por nela verem um excessivo rigor. Com isso, "o deus teve de repetir a sua ordem" para que as bacantes, "num impulso não menos repentino que o das alvas pombas", agissem, conforme as ordens de Dioniso. O que vemos depois desta ação é o desespero de Penteu, que tenta, em vão, ser reconhecido por sua mãe e fugir das mãos das bacantes que o estraçalham (vv. 1480-1486):

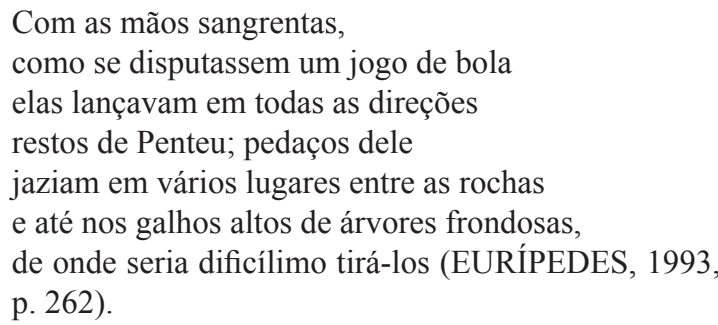

$\mathrm{Na}$ estrofe euripidiana citada, vimos uma das mais esclarecedoras passagens do que consiste o kydos, de sua maneira epifânica de aparição e, principalmente, como o "menor acontecimento violento tende a transformar-se em bola de neve, tornando-se irreversível" (GIRARD, 2008a, p. 191).

Na 3 a estrofe do coro de Perdição, o erotismo, já

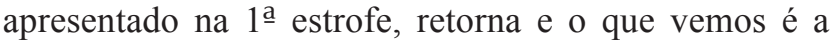
evocação das bacantes por um frescor sem freios, que somente Dioniso pode proporcionar aos seus devotos e, momentaneamente, os argumentos díspares cessam:

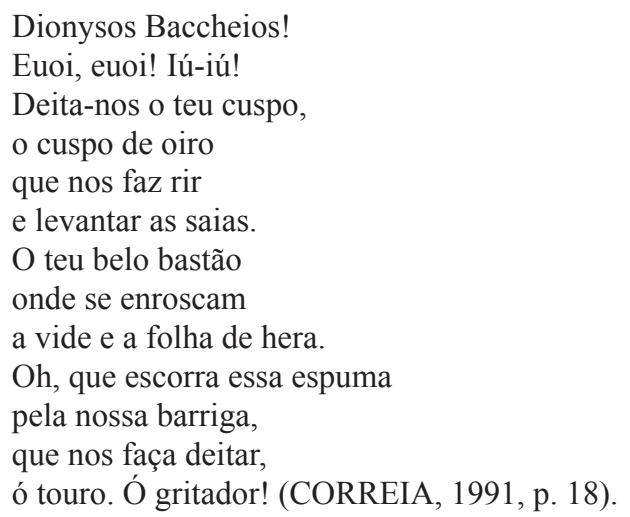


De cunho nietzschiano, a estrofe nos adverte para a possibilidade de que esta alegria, esta festa, seja a única maneira de atingirmos a verdade, pois, segundo o Nietzsche de $O$ Nascimento da Tragédia (1872), para viver, é preciso inventar ilusões, máscaras, vestes.

$\mathrm{Na}$ 4a estrofe, a evocação ao deus é ouvida e, assim, elas anunciam a sua vinda: "Chegou o ruidoso 4 !" (CORREIA, 1991, p. 18),

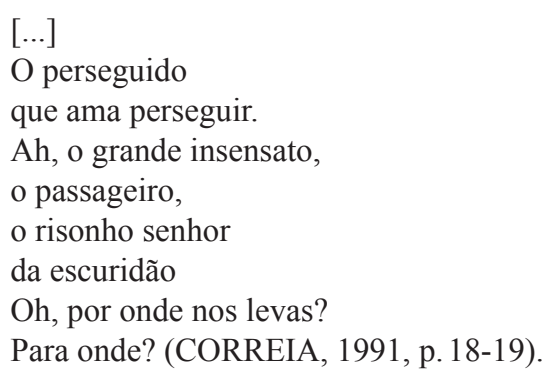

No segundo episódio d'As bacantes euripidiana, vemos Tirésias implorando a Penteu, "com espírito doente", que adira a [seu] delírio (vv.414). Neste apelo, o adivinho argumenta que o rei está louco por decidir perseguir a Dioniso. Já em Perdição, o deus é, a um só tempo, denominado perseguido e perseguidor. Lembremos que Dioniso, no prólogo d'As Bacantes, prometeu e cumpriu tresloucar as mulheres de Tebas, tornando-as bacantes, porém, antes, já havia sofrido com muitas perseguições que antecediam, inclusive, o seu nascimento. Assim, segundo Brunel (2000), Dioniso também é apresentado

$$
\begin{aligned}
& \text { como um deus perseguido: ora ele é dilacerado, cozido } \\
& \text { e devorado pelos Titãs, e Deméter o traz de volta à } \\
& \text { vida, ora Hera, em sua vingança, enlouquece a irmã de } \\
& \text { Sêmele, Ino, primeira mãe adotiva do deus, e os piratas } \\
& \text { o raptam para vendê-lo" (BRUNEL, 2000, p. 233). }
\end{aligned}
$$

Em Perdição, as bacantes, mesmo entontecidas, encerram a $4 \underline{a}$ estrofe questionando a validade de suas ações: "Temos o deus em nós. / É isto o amor?" (CORREIA, 1991, p. 19). Nesta afirmação, seguida de um questionamento ambíguo, tanto pode ocorrer a paródia pós-moderna da incompreensão das bacantes euripidianas, acerca da ordem dada por Dioniso, que teve de ser repetida, como vimos anteriormente, como também podemos estar diante da possibilidade de que "possuir o deus em si" seja sinonímico a se deixar tomar pelo ressentimento. Lembremos que Nietzsche constatou que este sentimento

[...] se torna criador e gera valores: o ressentimento dos seres aos quais é negada a verdadeira reação, a dos atos, e que apenas por uma vingança imaginária obtêm reparação [...] sua ação é no fundo reação (NIETSZCHE, 2010, p. 28-29).

\footnotetext{
4 Este é um dos epítetos de Dioniso.
}

A citação acima é de suma importância para a análise de Perdição, pois veremos personagens tomadas ou mesmo dominadas pelo ressentimento, o qual Nietzsche acima explica, pois, observaremos que Hélia Correia se vale e se valerá deste mesmo ressentimento como força inventiva de gestos, ações, reações (no caso da peça, ações perversas, pervertidas das personagens). Para nós, ocorre o mesmo no questionamento final da 4 a estrofe do coro de suas bacantes.

A 5 ${ }^{\underline{a}}$ estrofe inicia como as demais: as bacantes longe da vida rotineira das mulheres tebanas e suas máscaras sociais. Porém, a entrega ao prazer que o deus pode lhes proporcionar traz um sabor amaríssimo no fim, visto que também aponta ironicamente para a nossa necessidade de crermos neste falso consolo travestido de grandioso ato:

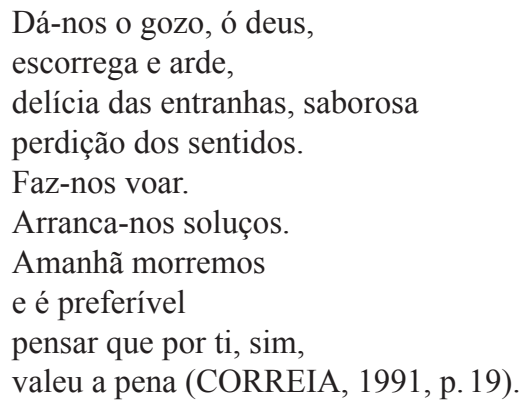

Em Eurípedes, as bacantes se autodenominam "cadelas céleres de raiva" (vv.1273), alcunha que, segundo nota de Gama Kury, refere-se à vingança. Isso ocorre quando, ainda tomadas pelo deus, comentam as atitudes de Penteu em repudiar Dioniso, para, logo em seguida, refletirem, com argumentos díspares (vv. 13091314), sobre seu "cortejo estrídulo" (vv. 1332):

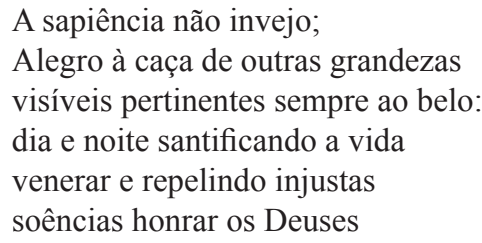

Para nós, a disparidade argumentativa não está na rejeição à sapiência, à astúcia dos homens, ao saber instrumental de Penteu, que não é sabedoria, como vemos a seguir (vv. 395-999):

A sapiência não é sabedoria, ter-se por imortal também não.

Breve é a vida, e assim quem a perseguir grandezas não colheria o presente? (EURÍPEDES, 1995, p. 69-70). 
A justa rejeição à sapiência deveria conduzir ao seu oposto, neste caso, à sabedoria. As bacantes, no entanto, optam pelo que, no fundo, é o mesmo, pois escolhem a outra face da moeda, as "outras grandezas visíveis pertinentes sempre ao belo". Essas "outras grandezas", embelezadas na piedade do culto, escondem, nesses ornatos, o seu verdadeiro caráter de violência sacrificial ("vinde porta-espada/matar por decapitação"). Fica com isso desnudada a contradição intrínseca na argumentação da mênades, pois "quem a perseguir grandezas não colheria o presente?"

Assim, tomadas pela fúria do deus do momento, elas aceitam a sua condição de "bicho", que será tão bem questionada no coro de bacantes de Hélia Correia.

A 6a estrofe do ditirambo de Perdição descreve outro importante aspecto ritual do dionisismo, a omofagia, a ingestão de carne crua:

\author{
Gemente, \\ com o som da agonia. \\ A carne, \\ a doce carne que fumega. \\ O corpo desmembrado das pequenas \\ criaturas macias. \\ Dos cabritos. \\ Dos filhos das mulheres. \\ Das gazelinhas cuja pele \\ depois \\ lançamos sobre os ombros (CORREIA, 1991, p. 20).
}

Com o fito de, ainda nesta estrofe, constatar a dubiedade das ações do deus, entoa o coro: "Ó deus, tu que enlouqueces a quem amas / tanto como a quem queres / aniquilar" (CORREIA, 1991, p. 20). Os atributos contraditórios e díspares são comuns a Dioniso. Na segunda antístrofe de As Bacantes, as mênades reiteram a generosidade de Dioniso, "o santo príncipe das criaturas bem-aventuradas" (vv.512) e, referindo-se a Penteu, cantam que "as falas sem freios [...] conduzem ao infortúnio" (vv. 522-523), ou seja, o generoso deus é intransigente com aqueles que não o cultuam.

$\mathrm{Na} 7 \underline{a}$ estrofe, descrentes, pessimistas, elas denunciam e lamentam a ação do tempo, cuja passagem inexoravelmente conduz ao esquecimento de tudo, até mesmo daquilo que merece ser conservado pela memória:

\footnotetext{
Toda a história do mundo

há-de esvair-se

como nossas pegadas.

Deus da treva

e do uivo.

Fiquem uivos

e trevas

porque não há memória

e a alma esquece,

seja qual for o modo

de existir" (CORREIA, 1991, p. 21).
}

Mais uma vez, ouvimos referências nietzschianas e pós-modernas que, em comum, relativizam a narrativa histórica, a interpretação do mundo e os seus valores. $\mathrm{O}$ esquecimento do passado é temática recorrente em Perdição.

Já na $8^{\text {a }}$ estrofe, Hélia Correia nos faz pensar se não estamos diante de uma crítica ao eterno retorno nietzschiano, que nos condena a estarmos presos para sempre num círculo de acontecimentos que se repetem e se esvaziam de sentido:

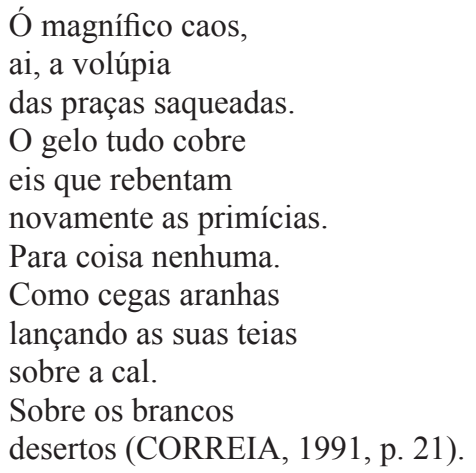

Esta estrofe traz também duas importantes reflexões críticas. A primeira é semelhante à feita por Tirésias, em seu Prólogo, sobre a volúpia sentida diante da destruição perpetrada pelos heróis, os responsáveis pelas "praças saqueadas". Já a outra questiona a validade das ações das bacantes, que terão como prêmio final o amor pela morte que nada gera, "sobre a cal", "sobre os brancos desertos". Assim, o kydos se mostra como o que realmente é: "nada. [...] [Como] o signo de uma vitória temporária, de uma vantagem imediatamente colocada em questão (GIRARD, 2008a, p. 193).

$\mathrm{Na} 9^{a}$ estrofe, após tão duras afirmações na estrofe anterior, as bacantes reforçam a denúncia do caráter ilusório dos seus atos, visto que a cegueira a que estão acometidas as leva "para coisa nenhuma", para, logo em seguida, entregarem-se completamente, rendidas ao deus:

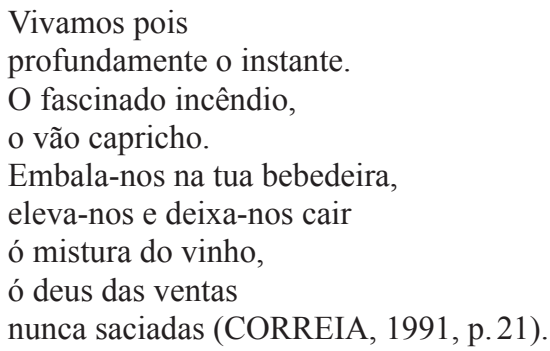

Sobre o vocábulo thymos, Nascimento (2009) observa que

[...] thymos deriva da raiz indo-europeia $d h e u$, que significa "acender em chamas", "surgir em uma nuvem", "fumar" (de uma pessoa indignada se diz 
que ela solta fumaça). Em sânscrito o vocábulo era dhuna, do qual vêm fumaça e perfume. Na Bíblia, e mais concretamente no Livro dos Reis, se faz também alusão a thymos como causa da raiva e da paixão (NASCIMENTO, 2009, p. 66).

O "fascinado incêndio", que é somente um "vão capricho", não estaria relacionado à fumaça (thymos) proveniente do sacrifício aos deuses, que Nascimento (2009) tão bem averiguou se referir a "surgir em uma nuvem", "fumar" (de uma pessoa indignada se diz que ela solta fumaça) e, principalmente, ao aludir no Livro dos Reis "como causa da raiva e da paixão" (NASCIMENTO, 2009, p. 66)? Cogitamos esta possibilidade a partir da constatação girardiana de que "fazer fumaça, sacrificar e também agir com violência, perder o controle" (GIRARD, 2008a, p. 193) originam-se do mesmo termo. Com base nisto, as bacantes, ao mostrarem que "vem e vão", ao sabor da violência dionisíaca, tornam-se simples ferramentas de destruição para Dioniso que, tomado por sua insaciável sede de vingança, nada - de fato - disputa. Desta forma, a ação das bacantes helianas, nada mais é, do que um passatempo para o deus.

Por isso, na $10^{\underline{a}}$ e última estrofe, ainda "à roda, à roda", ou seja, tomadas pelo delírio báquico, enceguecidas, tornam-se bichos, mas não demostram estar "céleres de raiva" como as bacantes euripidiana:

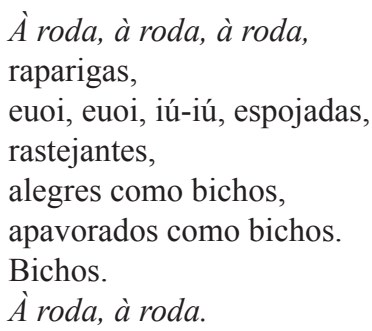

Seabra Pereira (2008b), ao analisar a presença da morte na literatura, atenta para a angústia com sua vinda iminente, o modo como ela vem e as cerimônias após a sua chegada. Com base em Philippe Ariès, o crítico português verifica o seguinte:

- Na Idade Média, a morte domada era a aceita como destino natural;

- No final do século XIX, a morte romântica era desejada pois, segundo Ariès, o Romantismo era "o tempo das belas mortes". Assim, buscava-se a doçura narcótica da morte na morte por amor ou, em geral, naquela que servia como fuga do envelhecimento.

- Já no século XX, temos o que o autor chama de morte invertida, que é a morte negada.

Como vimos, as bacantes helianas estão apavoradas, rastejantes e, por isso, ironicamente, alegres, diante da conquista da "doçura narcótica da própria morte", como tão bem assinalou Seabra Pereira (2008b), com base em Ariès, ao analisar a morte romântica.

Deste modo, vemos em Perdição que esta conquista mordaz ganha a mesma feição da conquista de Agave ainda inebriada pelo deus, anunciada pelo Corifeu (vv. 1560-1562): Ah! Infeliz!... Exibe aos cidadãos de Tebas / a tua presa, o belo troféu da vitória / que vens trazendo, eufórica, em tuas mãos! (EURÍPEDES, 1993, p.267).

\section{Conclusão}

Sonia Pereira (2009), ao analisar o ditirambo de Perdição, observa que ele

[...] apresenta uma estrutura (quase) semelhante aos hinos do culto dionisíaco. O Coro não se centra na genos, mas apenas na physis e no dynamis, ou seja, é dada atenção aos atributos e ao poder do deus, não prestando muito interesse à sua genealogia. A dramaturga cria um hino cheio de força e frescura, deixando transparecer uma despreocupada alegria, em comunhão com a natureza e com o deus, tal como o párodo das Bacantes de Eurípides (PEREIRA, 2009, p. 47).

No que tange à ênfase nos atributos de Dioniso, concordamos com a autora do trecho acima, afinal de contas, são suas ações que são apontadas. Porém, não comungamos da mesma opinião sobre "a despreocupada alegria" das bacantes em sua "comunhão com a natureza e com o Deus". Em Perdição, o coro de Hélia pode até parecer, de início, ter um fim em si mesmo, tamanha é sua emoção lírica, mas não o tem. Como já assinalamos, há indícios no texto que nos fazem crer em uma denúncia, por parte da autora, do mecanismo do bode expiatório como a "tragédia da humanidade" (GIRARD, 2011, p.217).

Já mencionamos também que esse coro não dialoga diretamente com os demais personagens de Perdição, mas é fundamental para compreendermos o percurso de Antígona rumo ao trágico. Isto ocorre porque é ele que Antígona vê, ouve e, por isso, teme, mesmo que se sinta atraída pelo seu suposto alento. É esse alento, vigor, pujança que investigamos em nossa tese de doutorado, pois, Hélia Correia questiona sua validade no drama.

Maria de Fátima Silva faz mais observações pertinentes para este artigo, ao constatar que a protagonista Antígona está fora do lugar. Não tem lugar. Foi animalizada e, sendo assim, como voltar a ser humana?

Esta análise de Silva é de crucial importância porque só reforça a proximidade percebida na condição de Antígona com a das bacantes. Cremos ter deixado 
claro quão ilusória é a satisfação que estas entoam. Afinal de contas, mostram-se perdidas, entregues ao deus que é um 'perseguido que ama perseguir', embora, contraditoriamente, também pronunciem um conformismo por serem "alegres como bichos" (CORREIA, 1991, p.22). Para nós, o caráter irônico impera em todo coro, inclusive, na pergunta final que o encerra: "será isto o amor?" (CORREIA, 1991, p.22). Assim, ao inserir um coro em seu drama contemporâneo, Hélia Correia nos leva a crer que o que ouvimos retoma uma dor antiga, ainda não amplamente ouvida por estar ainda encoberta pelo "véu poético" que tão bem Girard detectou ter sido lançado sob as tragédias gregas e que nasce da busca por algo tão enganoso, embora fascinante, como o kydos.

\section{Referências}

ARISTÓTELES; HORÁCIO; LONGINO. A poética clássica. Tradução de Jaime Bruna. 7. ed. São Paulo: Cultrix, 1997.

ARISTÓTELES. Ética a Nicômaco. Bauru: Edipro, 2009.

BERTHOLD, Margot. História Mundial do Teatro. São Paulo: Perspectiva, 2008.

BÍBLIA DE JERUSALÉM. São Paulo: Paulus, 2004.

BRANDÃO, Junito. Mitologia grega. Rio de Janeiro: Vozes, 1992. $3 \mathrm{v}$.

BRUNEL, Pierre (Org.). Dicionário de Mitos Literários. 3. ed. Rio de Janeiro: José Olympio, 2000.

CORREIA, Hélia. Perdição: exercício sobre Antígona. Lisboa: Relógio d'Água Editores, 2001.

EURÍPEDES. As bacas. Estudo e tradução de Jaa Torrano. São Paulo: Hucitec, 1995.

Ifigênia em Áulis; As Fenícias; As Bacantes. Tradução de Mário da Gama Kury. Rio de Janeiro: Jorge Zahar, 1993.

GIRARD, René. A conversão da arte. Tradução de Lília Ledon da Silva. São Paulo: É Realizações, 2011.

A violência e o sagrado. Tradução de Martha Gambini. 3. ed. São Paulo: Paz e Terra, 2008a.

Coisas ocultas desde a fundação do mundo: a revelação destruidora do mecanismo vitimário. Tradução de Martha Gambini. São Paulo: Paz e Terra, 2008b.

Mentira Romântica e verdade romanesca. Tradução de Lilia Ledon da Silva. São Paulo: É Realizações. 2009.

GRIMAL, Pierre. Dicionário da mitologia grega e romana. Tradução de Victor Jabouille. 2. ed. Rio de Janeiro: Bertrand Brasil, 1993.
HUTCHEON, Linda. A poética do pós modernismo. Rio de Janeiro: Imago, 1988.

MANOJLOVIC, Tatjana. Personagens da tragédia grega no drama português contemporâneo: demanda da identidade na tríade de Hélia Correia. 2008. 131 fl. Tese (Doutorado em Letras) - Faculdade de Letras, Centro de Estudos de Teatro, Universidade de Lisboa, 2008. Disponível em: $<$ http://hdl. handle.net/10451/573>. Acesso em: 12 fev. 2011.

NASCIMENTO, Dulcileide V. do. Entre laços e palavras o thymós na poesia elegíaca de Mimnermo de Cólofon. In: Círculo Fluminense de Estudos Filológicos e Linguisticos. Rio de Janeiro: CIFEFIL, 2009. Disponível em: <http://www. filologia.org.br/xiicnlf/13/06.pdf>. Acesso em: 05 fev. 2013.

NIETSZCHE, Friedrich. Genealogia da Moral. Tradução Paulo Cezar de Souza. São Paulo: Companhia da Letras. 2010.

PEREIRA, Sonia Margarida Fernandes. A reescrita de mitos clássicos no teatro de Hélia Correia. 2009. 116 fl. Dissertação (Mestrado em Letras) - Faculdade de Letras da Universidade de Coimbra, 2009. Disponível em: <https://estudogeral.sib. uc.pt/.../1/Tese mestrado_Sofia\%20Pereira.pdf $>$. Acesso em: 16 jun. 2010.

PIMENTEL, Samarkandra Pereira dos Santos. Paródia e mecanismo mimético em Perdição: Exercício sobre Antígona. $225 \mathrm{fl}$. Tese (Doutorado em Letras) - Universidade Federal da Paraíba, João Pessoa, 2014. Disponível em: <http://tede.biblioteca.ufpb. br:8080/handle/tede/6297>. Acesso em: 16 jun. 2015.

SILVA, Maria de Fátima Sousa e. (Coord.). Furor: ensaios sobre a obra dramática de Hélia Correia. Coimbra: Impressa da Universidade de Coimbra, 2006.

RYNGAERT, Jean-Pierre. Ler o teatro contemporâneo. São Paulo: Martins Fontes, 1998.

SEABRA PEREIRA, José Carlos. Alotropia e desejo de plenitude na modernidade ocidental. In: SEMANA CULTURAL DA UC, X., 2008a.

Frágil contingência e terna solicitude na literatura contemporânea. In: Revista Portuguesa de Bioética, n. 6, p. 349-368, dez. 2008b.

SCHEIDT, Déborah. A "muralha viva" da tragédia grega: o coro e suas sutilezas. Campo Mourão: Revista Nupem, v. 2, ago./dez. 2010.

SÓFOCLES. A trilogia tebana. Tradução de Mario da Gama Kury. Rio de Janeiro: Jorge Zahar Editor, 1990.

Antígona. Tradução de Maria Helena da Rocha Pereira. Lisboa: Calouste Gulbenkian, 1992.

Recebido: 14 de outubro de 2015 Aprovado: 25 de março de 2016 Contato:kandra@gmail.com 